\title{
Characterization of a New Obligately Anaerobic Thermophile, Thermoanaerobacter wiegelii sp. nov.
}

\author{
GREGORY M. COOK, ${ }^{1 *}$ FREDERICK A. RAINEY, ${ }^{2}$ BHARAT K. C. PATEL, ${ }^{1}$ AND HUGH W. MORGAN ${ }^{1}$ \\ Thermophile and Microbial Biochemistry and Biotechnology Unit, University of Waikato, Hamilton, New Zealand, ${ }^{1}$ \\ and German Collection of Microorganisms and Cell Cultures, Braunschweig, Germany ${ }^{2}$
}

\begin{abstract}
An obligately anaerobic, extremely thermophilic Thermoanaerobacter species was isolated from a freshwater pool formed from a geothermally heated $\left(56\right.$ to $\left.69^{\circ} \mathrm{C}\right)$ water outlet in Government Gardens, Rotorua, New Zealand. This organism was a spore-forming, gram-negative, rod-shaped bacterium. Strain Rt8.B1 ${ }^{\mathrm{T}}(=\mathrm{DSM}$ $\left.10319^{\mathrm{T}}\right)(\mathrm{T}=$ type strain) fermented a wide variety of mono-, di-, and polysaccharides and produced ethanol, acetate, lactate, propionate, and hydrogen. Sugar alcohols were also fermented, but organic acids and amino acids were not utilized. On the basis of its morphological characteristics, DNA G+C content, obligately anaerobic, thermophilic, polysaccharolytic nature, and levels of 16S rRNA sequence homology, we propose that strain Rt8.B1 ${ }^{\mathrm{T}}$ should be classified in the genus Thermoanaerobacter as a new species, Thermoanaerobacter wiegelii.
\end{abstract}

The thermophilic, anaerobic, saccharolytic bacteria include species that belong to the genera Clostridium, Thermoanaerobium, Thermoanaerobacter, and Thermoanaerobacterium (18, 34). Until recently, the genus Thermoanaerobacter contained only two species, Thermoanaerobacter ethanolicus (type strain, strain JW200) (35) and Thermoanaerobacter finnii (30). Type strain JW200 of the type species of this genus, Thermoanaerobacter ethanolicus (37), was isolated from hot springs located in Yellowstone National Park by Wiegel and Ljungdahl (35). This organism was described as a gram-variable, rod-shaped, non-spore-forming, obligately anaerobic thermophile with a DNA G + C content of 37 to $39 \mathrm{~mol} \%$ (35). On the basis of the results of DNA-DNA hybridization and total-cell-protein analyses, Lee et al. (18) redefined the genus Thermoanaerobacter so that it included Thermoanaerobacter brockii (40) (formerly Thermoanaerobium brockii HTD4), as well as Thermoanaerobacter thermohydrosulfuricus E100-69 (12) and Thermoanaerobacter ethanolicus 39E (39) (formerly Clostridium thermohydrosulfuricum E100-69 and 39E, respectively).

The results of a phylogenetic analysis of the majority of the thermophilic anaerobic bacteria indicated that Thermoanaerobacter ethanolicus, Thermoanaerobacter brockii, Thermoanaerobacter thermohydrosulfuricus, and Thermoanaerobacter finnii formed a distinct phylogenetic cluster which also included Thermobacteroides acetoethylicus, Acetogenium kivui, and Clostridium thermocopriae (29). Thermobacteroides acetoethylicus was subsequently transferred to the genus Thermoanaerobacter as Thermoanaerobacter acetoethylicus (28). On the basis of the 16S ribosomal DNA (rDNA) data of Rainey et al. (29), Collins et al. (4) included Thermoanaerobacter thermocopriae (formerly Clostridium thermocopriae [14]) and Thermoanaerobacter kivui (formerly Acetogenium kivui $[19,20]$ ) in this genus.

In this paper we describe the characteristics of an obligately anaerobic, extremely thermophilic strain, strain $\mathrm{Rt} 8 . \mathrm{B} 1^{\mathrm{T}}$ ( $\mathrm{T}=$ type strain). Strain Rt8.B1 $1^{\mathrm{T}}$ differs from other Thermoanaerobacter species in the following characteristics: spore formation, ability to ferment sugar alcohols, ability to produce propionate from xylose, ability to ferment cellobiose, $\mathrm{pH}$ range for

${ }^{*}$ Corresponding author. Present address: Division of Life Sciences, King's College London, Campden Hill Road, London W8 7AH, United Kingdom. Phone: 440171333 4023. Fax: 4401713334500. Electronic mail address: UDLI161@bay.cc.kcl.ac.uk. growth, and antibiotic susceptibility. The results of a $16 \mathrm{~S}$ rDNA sequence analysis also showed that this organism differs from other Thermoanaerobacter species. In this paper we propose the name Thermoanaerobacter wiegelii sp. nov. for strain Rt8.B1 ${ }^{\mathrm{T}}$.

\section{MATERIALS AND METHODS}

Sampling procedure. Samples from a freshwater pool formed by a water outlet of a heat exchanger in Government Gardens, Rotorua, New Zealand, were collected in sterile $30-\mathrm{ml}$ universal bottles. Each collection vessel was completely filled, sealed with a gas-tight septum, and tightly capped. All samples were transported to the laboratory and stored at ambient temperature for future use. The pool water had a $\mathrm{pH}$ range of 8.3 to 9.1 , and the temperature ranged from 56 to $69^{\circ} \mathrm{C}$

Medium and culture conditions. The new isolate strain $\mathrm{Rt} 8 . \mathrm{B} 1^{\mathrm{T}}$ was maintained by fortnightly subculture on a modified Trypticase peptone-yeast extract medium of Zeikus et al. (40) (the yeast extract and Trypticase peptone concentrations were reduced to 1 and $2 \mathrm{~g} /$ /iter, respectively). The medium was prepared anaerobically as described by Patel et al. (22). The $\mathrm{pH}$ of the medium was adjusted to $\mathrm{pH} 7$ by adding $1 \mathrm{~N} \mathrm{NaOH}$, and the medium was autoclaved at $121^{\circ} \mathrm{C}$ for $20 \mathrm{~min}$. For solidified media $20.0 \mathrm{~g}$ of purified Oxoid agar (Unipath, Basingstoke, Hampshire, England) per liter was added.

Carbon sources were prepared anaerobically in distilled water as concentrated stock solutions and were sterilized by autoclaving. Each carbon source was added to sterile media to a final concentration of $5 \mathrm{~g} /$ liter. All of the sugars were $D$ isomers unless indicated otherwise. Antibiotics were added at concentrations of 10 to $100 \mu \mathrm{g} / \mathrm{ml}$, and the resulting growth was compared with the growth of control preparations (with no antibiotic added) after $24 \mathrm{~h}$ of incubation. The preparations were incubated at $65^{\circ} \mathrm{C}$ unless indicated otherwise. Plates were incubated in stainless steel anaerobic jars under an $\mathrm{N}_{2}$ gas atmosphere.

Cellular characterization. The methods used to prepare cells for thin sectioning and electron microscopic examination were the methods described by Patel et al. (23). Thin sections were stained with $1 \%$ (wt/vol) uranyl acetate and then with $1 \%$ (wt/vol) lead citrate and then examined with a Philips model EM 400 electron microscope at an accelerating voltage of $80 \mathrm{kV}$.

$16 S$ rDNA sequence analysis. Genomic DNA was isolated, and the 16S rDNA was amplified as described previously (27). PCR products were sequenced by using a Taq Dye Deoxy Terminator cycle sequencing kit (Applied Biosystems, Foster City, Calif.) as recommended by the manufacturer. Purified sequence reaction mixtures were electrophoresed by using an Applied Biosystems model $373 \mathrm{~A}$ DNA sequencer. The $16 \mathrm{~S}$ rDNA sequence of strain Rt8. B1 ${ }^{\mathrm{T}}$ was manually aligned with previously published $16 \mathrm{~S}$ rDNA sequences of representatives of the genus Clostridium and related taxa. The method of Jukes and Cantor (15) was used to calculate evolutionary distances, from which a phylogenetic dendrogram was reconstructed by using the algorithm of De Soete (10).

$\mathbf{G}+\mathbf{C}$ content. The guanine-plus-cytosine $(\mathrm{G}+\mathrm{C})$ content of the DNA was determined by high-performance liquid chromatography (HPLC) as described by Mesbah et al. (21).

Other analyses. Fermentation product and substrate concentrations in medium samples were determined by HPLC as described previously (9). Sodium succinate was used as an internal standard. Gaseous end products were analyzed by gas chromatography by using a model PU 4500 gas chromatograph (Pye Unicam, Cambridge, England) equipped with a thermal conductivity detector as 
described by Patel et al. (23). The growth rate constant for the exponential phase of growth was determined by plotting the $\log _{10}$ of optical density against time (26). The cellular polysaccharide content was determined by the anthrone method (32). The presence of heat-resistant endospores was demonstrated as described previously (5). Indole production, gelatin hydrolysis, and esculin hydrolysis were studied by using standard methods (32).

Nucleotide sequence accession number. The $16 \mathrm{~S}$ rDNA sequence of strain Rt8.B1 ${ }^{\mathrm{T}}$ has been deposited in the EMBL database under accession number X92513.

\section{RESULTS}

Enrichment and isolation. Trypticase peptone-yeast extractglucose (TYEG) medium (40) was used for enrichment of strain Rt8.B1 ${ }^{\mathrm{T}}$. Primary enrichment cultures were prepared by adding $0.2 \mathrm{ml}$ of pool water to $10 \mathrm{ml}$ of prereduced TYEG medium under an $\mathrm{N}_{2}$ atmosphere. After 1 to 3 days at $70^{\circ} \mathrm{C}$, gas production and visible turbidity were observed, indicating substrate utilization was occurring. All positive cultures were transferred and incubated at least three times in the same media, after which they were purified in TYEG agar deeps ( $2 \%$ [wt/vol] agar). Pure cultures of strain $\mathrm{Rt} 8 . \mathrm{B} 1^{\mathrm{T}}$ were then stored at $-20^{\circ} \mathrm{C}$ in a glycerol-medium mixture (50:50).

Cellular features. Cells grown on solid TYEG medium produced nonpigmented colonies (diameter, 0.5 to $2.0 \mathrm{~mm}$ ) that were smooth and uniformly round. Cells obtained from isolated colonies were gram-negative rods that were 0.4 to $0.6 \mu \mathrm{m}$ wide by 4 to $10 \mu \mathrm{m}$ long. The cells occurred singly, in pairs, or (less frequently) in chains. Cells grown on TYEG medium did not sporulate. When the organisms were grown in a minimal medium (5), the cells were long and filamentous and spores were produced. The spores were round and terminal, distended the cells, and were brightly refractile as determined by phase-contrast microscopy (24). Cultures grown on minimal medium at $65^{\circ} \mathrm{C}$ (conditions that induced sporulation) survived more than $80 \mathrm{~min}$ of exposure to $115^{\circ} \mathrm{C}$, thus confirming that they were heat resistant.

Electron micrographs of ultrathin sections of strain Rt8.B $1^{\mathrm{T}}$ are shown in Fig. 1. Figure 1a shows a single cell with distinct cell envelope layers. The cells appeared to divide where two membrane invaginations arosen from displaced positions to give an $\mathrm{S}$-shaped appearance. Figure $1 \mathrm{~b}$ shows cell division at a latter stage in the cycle. Cell division appeared to occur via a septation mechanism, and a high percentage $(70 \%)$ of the cells exhibited this type of division. A higher magnification of the cell wall revealed a two-layer structure (Fig. 1c). The inner layer, which was adjacent to the cytoplasmic membrane, stained intensely, whereas the outer layer was less dense. The cells were sluggishly motile, and flagella were peritrichous (24).

Antibiotic susceptibility. Cephalosporin C, erythromycin, bacitracin, tetracycline, or polymyxin B completely inhibited growth at a concentration of $10 \mu \mathrm{g} / \mathrm{ml}$ of medium. Trimethoprim, rifampin, amphotericin B, D-cycloserine, penicillin $G$, streptomycin sulfate, chloramphenicol, and ampicillin did not inhibit growth at concentrations up to $100 \mu \mathrm{g} / \mathrm{ml}$.

The metabolic inhibitors monensin $(100 \mu \mathrm{M}), 2,4$-dinitrophenol $(500 \mu \mathrm{M})$, tetrachlorosalicylanilide $(10 \mu \mathrm{M}), N, N$-dicyclohexylcarboiimide $(500 \mu \mathrm{M})$, and iodoacetate $(500 \mu \mathrm{M})$ all inhibited growth when they were added to cultures that were growing exponentially on glucose. Sodium azide, sodium fluoride, potassium cyanide, and sodium arsenate completely stopped growth at $65^{\circ} \mathrm{C}$ when they were added to a final concentration of $5 \mathrm{mM}$. Oxygen completely inhibited growth.

Growth conditions of strain Rt8.B1 $1^{\mathbf{T}}$. Strain $\mathrm{Rt} 8 . \mathrm{B} 1^{\mathbf{T}}$ did not grow on TYEG medium lacking sodium sulfide reductant or cysteine- $\mathrm{HCl}$, indicating that anaerobic conditions were required for growth. Hydrogen sulfide was produced from sodium sulfite and sodium thiosulfate. Growth occurred at $\mathrm{pH}$

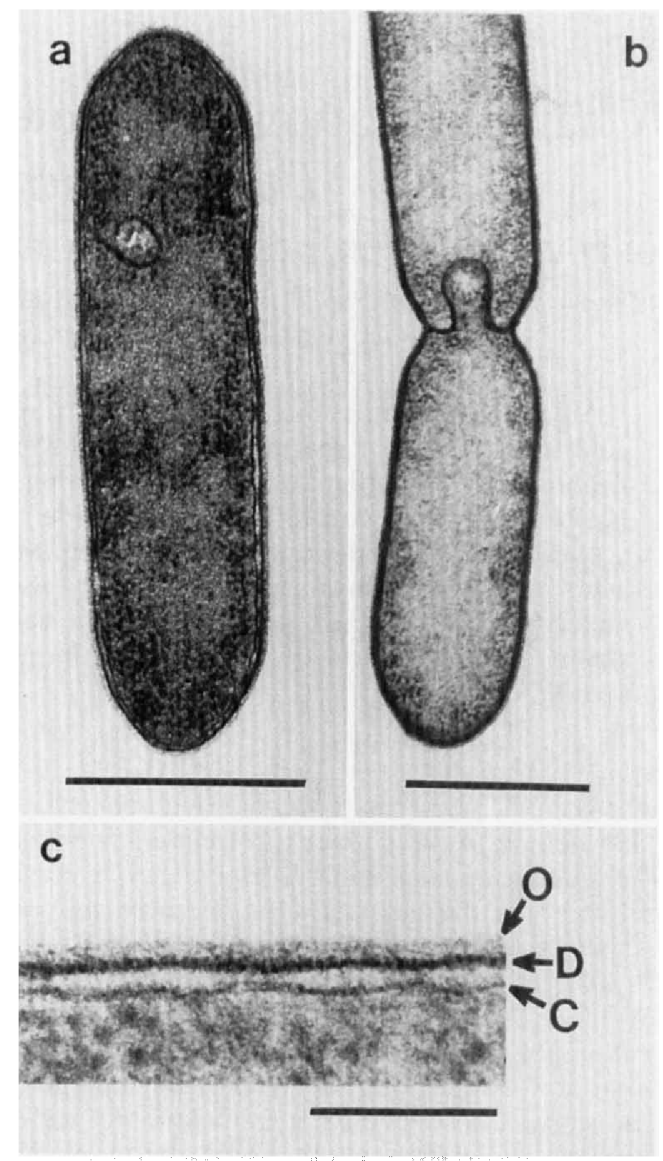

FIG. 1. Electron micrographs of ultrathin sections of strain $\mathrm{Rt} 8 . \mathrm{B} 1^{\mathrm{T}}$ grown on Trypticase peptone-yeast extract medium containing cellobiose. (a) Ultrathin section of strain Rt8. $\mathrm{B1}^{\mathrm{T}}$ showing cell wall layers. Note the characteristic structures resembling so-called mesomes in the cell. Bar $=0.5 \mu \mathrm{m}$. (b) Dividing cells at a later stage in cell division. Bar $=0.5 \mu \mathrm{m}$. (c) Higher magnification of the cell wall layers. Abbreviations: $O$, outer cell wall layer; $D$, dense layer; $C$, cytoplasmic membrane. $\mathrm{Bar}=0.1 \mu \mathrm{m}$.

5.5 to 7.2 , but not at pH 5.0 or 7.25 in pH-controlled batch cultures. The optimum $\mathrm{pH}$ for growth was 6.8 . The temperatures at which growth occurred ranged from 38 to $78^{\circ} \mathrm{C}$, and the optimum temperature was between 65 and $68^{\circ} \mathrm{C}$. No growth occurred at 34 or $80^{\circ} \mathrm{C}$.

Growth substrates. Strain Rt8.B1 $1^{\mathrm{T}}$ did not exhibit an absolute growth requirement for yeast extract or Trypticase, and both of these growth supplements could be replaced by vitamin-free Casamino Acids (5 g/liter) and vitamins (5). No growth occurred in Trypticase peptone-yeast extract medium in the absence of a fermentable carbon source. Glucose, xylose, maltose, lactose, cellobiose, raffinose, glucosamine, galactose, fructose, mannose, sucrose, glycerol, soluble starch, pectin, and chitin were used as fermentable substrates. Sorbitol, mannitol, and trehalose were also fermented, but ethanol, DL-lactate, sodium citrate, sodium succinate, transaconitate, malonate, glutamate, glutamine, sodium pyruvate, 2-deoxyglucose, $\alpha$-methyl-glucoside, L-arabinose, $\alpha$-L-rhamnose, dulcitol, $m$-inositol, ribose, $\alpha$-L-fucose, and L-sorbose were not fermented. Growth did not occur via reduction of nitrate, oxygen, sulfate, or sulfur when glucose was the sole carbon source. Indole was not formed from L-tryptophan. Esculin and gelatin were not hydrolyzed. Cells did not accumulate anthrone-reactive material when they were grown on glucose.

Phylogenetic position. We determined an almost complete $16 \mathrm{~S}$ rDNA sequence for strain Rt8.B1 ${ }^{\mathrm{T}}$ ( $>95 \%$ of the Esche- 


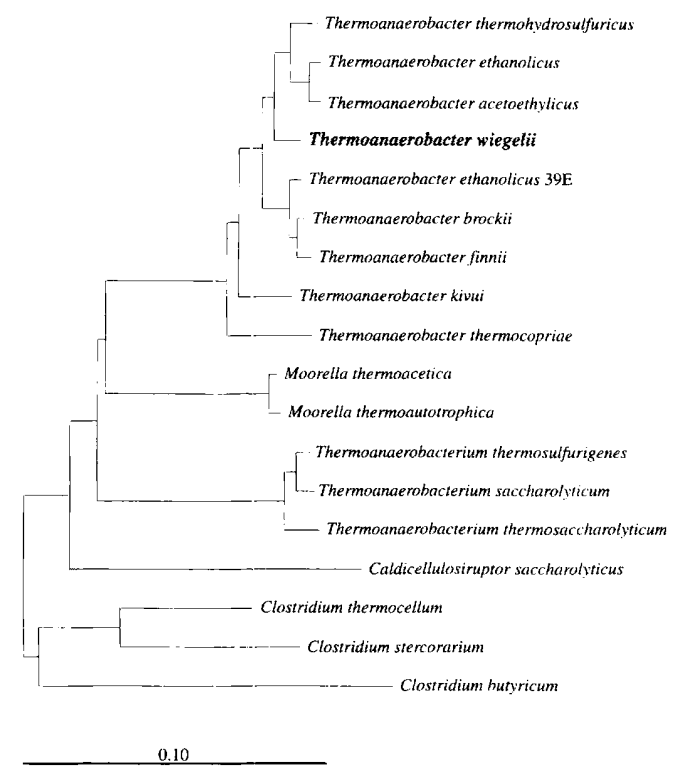

FIG. 2. Phylogenetic dendrogram showing the position of Thermoanaerobacter wiegelii $\mathrm{Rt} 8 . \mathrm{B} 1^{\mathrm{T}}$ within the radiation of the genus Thermoanaerobacter and related taxa. Scale bar $=10$ nucleotide substitutions per 100 nucleotides.

richia coli sequence). Our phylogenetic analysis of $16 \mathrm{~S}$ rDNA sequences placed strain Rt8.B $1^{T}$ in the cluster comprising members of the genus Thermoanaerobacter (Fig. 2). The $16 \mathrm{~S}$ rDNA sequence of strain Rt8.B1 $1^{\mathrm{T}}$ exhibited levels of similarity ranging from 95.2 to $98.2 \%$ with the sequences of the other organisms currently assigned to the genus Thermoanaerobacter (Table 1). The highest level of sequence similarity $(98.2 \%)$ was with the type strain of the type species of the genus Thermoanaerobacter, Thermoanaerobacter ethanolicus JW200.

\section{DISCUSSION}

Until recently, the descriptions of most extremely thermophilic (optimum growth temperature, 65 to $70^{\circ} \mathrm{C}$ ) anaerobic bacteria were based solely on phenotypic characteristics and DNA G $+C$ contents. Spore formation was used as a key taxonomic marker, and isolates in which spore formation had not been observed were described as members of the genera Thermoanaerobium, Thermoanaerobacter, and Thermobacteroides. On the basis of DNA-DNA hybridization, total-cell-protein, and $16 \mathrm{~S}$ rRNA gene sequence data $(4,18)$, the genus Thermoanaerobacter was redefined so that it included Thermoanaerobacter brockii, Thermoanaerobacter thermohydrosulfuricus E100-69, Thermoanaerobacter thermocopriae, and Thermoanaerobacter kivui.

Strain Rt8.B1 ${ }^{\mathbf{T}}$ was initially considered a Clostridium thermohydrosulfuricum strain because of its phenotypic characteristics $(6,24)$ and then was considered a Thermoanaerobacter thermohydrosulfuricus strain in subsequent publications (7-9) in accordance with the proposed nomenclature of Lee et al. (18). Thermoanaerobacter wiegelii $\mathrm{Rt} 8 \cdot \mathrm{B} 1^{\mathrm{T}}$ metabolizes glucose via the Embden-Meyerhof-Parnas pathway and exhibits hetero-ethanol fermentation (9), as described previously for other Thermoanaerobacter isolates (38). Pentoses are fermented via the pentose phosphate pathway (8). The major end products of glucose fermentation by strain Rt8.B $1^{\mathrm{T}}$ are formed from pyruvate via the following three routes: (i) a route to lactate via a $\mathrm{pH}$-dependent fructose-1,6-diphosphate-activated lactate dehydrogenase; (ii) a route to acetate via acetate kinase; and (iii) a route to ethanol via an irreversible NADP-linked alcohol dehydrogenase (9). NADP-activated alcohol dehydrogenases and fructose-1,6-diphosphate-activated lactate dehydrogenases have been found previously in Thermoanaerobacter finnii (30), Thermoanaerobacter ethanolicus (2), Thermoanaerobacter brockii (1, 16, 17), and Thermoanaerobacter thermohydrosulfuricus (11). Strain Rt8.B1 ${ }^{\mathrm{T}}$ lacks a phosphoenolpyruvate-dependent phos-

TABLE 1. Levels of $16 \mathrm{~S}$ rDNA sequence similarity for Thermoanaerobacter wiegelii and related taxa

\begin{tabular}{|c|c|c|c|c|c|c|c|c|c|c|c|c|c|c|c|c|}
\hline \multirow[b]{2}{*}{ Organism } & \multicolumn{16}{|c|}{$\% 16 \mathrm{~S}$ rDNA sequence similarity } \\
\hline & 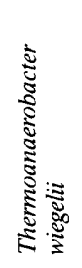 & 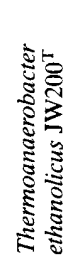 & 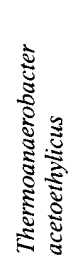 & 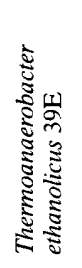 & 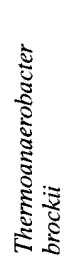 & 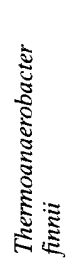 & 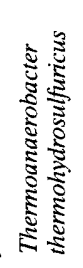 & 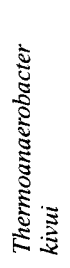 & 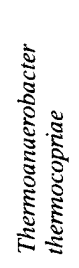 & 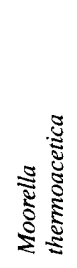 & 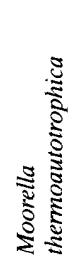 & 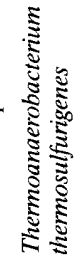 & 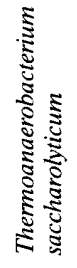 & 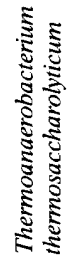 & 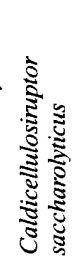 & 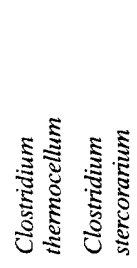 \\
\hline Thermoanaerobacter ethanolicus $\mathrm{JW} 200^{\mathrm{T}}$ & 98.2 & & & & & & & & & & & & & & & \\
\hline Thermoanaerobacter acetoethylicus & 97.9 & 99.2 & & & & & & & & & & & & & & \\
\hline Thermoanaerobacter ethanolicus $39 \mathrm{E}$ & 97.8 & 96.6 & 97.2 & & & & & & & & & & & & & \\
\hline Thermoanaerobacter brockii & 97.7 & 96.5 & 97.1 & 99.3 & & & & & & & & & & & & \\
\hline Thermoanaerobacter finnii & 97.3 & 96.2 & 96.7 & 98.9 & 99.3 & & & & & & & & & & & \\
\hline Thermoanaerobacter thermohydrosulfuricus & 97.3 & 98.2 & 97.9 & 96.5 & 96.9 & 96.5 & & & & & & & & & & \\
\hline Thermoanaerobacter kivui & 96.4 & 95.4 & 95.5 & 96.8 & 96.5 & 96.1 & 95.7 & & & & & & & & & \\
\hline Thermoanaerobacter thermocopriae & 95.2 & 94.1 & 94.2 & 95.3 & 95.2 & 94.9 & 94.0 & 94.4 & & & & & & & & \\
\hline Moorella thermoacetica & 89.3 & 88.2 & 88.3 & 88.8 & 89.3 & 89.1 & 88.5 & 89.1 & 88.3 & & & & & & & \\
\hline Moorella thermoautotrophica & 88.9 & 87.8 & 87.9 & 88.4 & 88.9 & 88.7 & 88.1 & 88.9 & 87.9 & 99.2 & & & & & & \\
\hline Thermoanaerobacterium thermosulfurigenes & 88.0 & 87.6 & 87.5 & 87.3 & 87.6 & 87.4 & 88.0 & 87.9 & 86.5 & 87.1 & 87.0 & & & & & \\
\hline Thermoanaerobacterium saccharolyticum & 87.1 & 86.9 & 86.9 & 86.9 & 87.3 & 87.0 & 87.2 & 87.6 & 86.1 & 87.0 & 87.0 & 98.6 & & & & \\
\hline Thermoanaerobacterium thermosaccharolyticum & 87.6 & 87.0 & 86.9 & 87.0 & 87.3 & 87.0 & 87.3 & 87.6 & 86.3 & 87.3 & 87.1 & 97.9 & 97.8 & & & \\
\hline Caldicellulosiruptor saccharolyticus & 85.4 & 84.5 & 84.7 & 85.4 & 85.2 & 85.0 & 84.3 & 85.2 & 85.6 & 84.2 & 84.2 & 83.7 & 83.4 & 83.9 & & \\
\hline Clostridium thermocellum & 84.4 & 83.6 & 83.4 & 84.6 & 84.7 & 84.0 & 83.7 & 84.8 & 85.0 & 86.0 & 85.8 & 84.8 & 84.9 & 85.2 & 84.6 & \\
\hline Clostridium stercorarium & 83.7 & 83.0 & 82.8 & 84.0 & 84.0 & 83.5 & 83.1 & 84.0 & 85.0 & 85.6 & 85.3 & 82.6 & 83.0 & 83.0 & 83.9 & 91.3 \\
\hline Clostridium butyricum & 81.3 & 80.9 & 80.8 & 81.0 & 80.9 & 80.5 & 81.0 & 81.1 & 80.8 & 82.7 & 82.3 & 82.0 & 81.7 & 82.5 & 79.0 & 84.181 .0 \\
\hline
\end{tabular}


photransferase system for glucose transport and relies on facilitated diffusion for glucose transport and xylose transport, which are followed by ATP-dependent phosphorylation by glucokinase and xylulokinase, respectively $(7,8)$.

Thermoanaerobacter wiegelii $\mathrm{Rt} 8 . \mathrm{B} 1^{\mathrm{T}}$ grows on a wide range of carbohydrates. An ethanol yield of up to $1.1 \mathrm{~mol}$ of ethanol per mol of substrate utilized was obtained with single substrates (9), but values of 1.56 to $1.7 \mathrm{~mol}$ of ethanol per mol of substrate utilized were obtained when substrates were supplied in combinations and were fermented simultaneously (9). These values are in the range reported previously for other thermophilic ethanologens, such as Thermoanaerobacter ethanolicus and Thermoanaerobacter thermohydrosulfuricus, which are capable of producing more than $1.5 \mathrm{~mol}$ of ethanol per mol of glucose utilized (33). Growth studies performed with Thermoanaerobacter wiegelii Rt8.B $1^{\mathrm{T}}$ demonstrated that glucose and xylose were used simultaneously when they were supplied together at nonlimiting concentrations in $\mathrm{pH}$-controlled batch cultures (6). A similar lack of diauxic growth on a glucosexylose substrate mixture has also been reported for Thermoanaerobacter ethanolicus (3).

The results of our 16S rDNA sequence analysis clearly placed Thermoanaerobacter wiegelii $\mathrm{R} t 8 . \mathrm{B} 1^{\mathrm{T}}$ in the cluster composed of species assigned to the genus Thermoanaerobacter. The results of our primary-structure alignment analysis indicated that the $16 \mathrm{~S}$ rDNA sequence of strain Rt8.B1 $1^{\mathrm{T}}$ did not contain any of the insertions that have been found in other thermophilic anaerobes (29). As shown previously, the genus Thermoanaerobacter is a distinct phylogenetic cluster, the significance of which was demonstrated by $100 \%$ recovery in a bootstrap analysis $(4,29)$. Strain Rt8.B1 ${ }^{\mathrm{T}}$ can be considered a member of the genus Thermoanaerobacter on the basis of phylogenetic analysis data. Designation of this strain as a member of a new species is also supported by the 16S rDNA sequence data. Figure 2 shows that strain $\mathrm{Rt} 8 . \mathrm{B} 1^{\mathrm{T}}$ represents a distinct branch within the Thermoanaerobacter cluster. Our data indicate that the levels of $16 \mathrm{~S}$ rDNA similarity between strain $\mathrm{Rt} 8 . \mathrm{B} 1^{\mathrm{T}}$ and other Thermoanaerobacter species are lower than the levels of similarity between some species previously assigned to this genus on the basis of DNA-DNA homology values.

Morphological and physiological characteristics of strain Rt8.B1 ${ }^{\mathrm{T}}$ were directly compared with the characteristics of other isolates belonging to the genus Thermoanaerobacter by using the data of Jain and Zeikus (13). Phenotypically, Thermoanaerobacter wiegelii $\mathrm{Rt}$ 8. $\mathrm{B} 1^{\mathrm{T}}$ differs from other members of the genus Thermoanaerobacter by the following characteristics: (i) its relatively narrow $\mathrm{pH}$ range for growth ( $\mathrm{pH} 5.5$ to 7.2); (ii) its antibiotic susceptibility; (iii) its ability to ferment some sugar alcohols; (iv) its growth in the absence of yeast extract; and (v) its formation of propionate when it is grown on xylose or cellobiose in $\mathrm{pH}$-controlled batch cultures $(\mathrm{pH} 7)$.

On the basis of the ability of Thermoanaerobacter wiegelii $\mathrm{Rt} 8 . \mathrm{B} 1^{\mathrm{T}}$ to form heat-resistant endospores, it seems reasonable to suggest that this strain may closely resemble the sporeforming members of the genus Thermoanaerobacter. Electron micrographs of ultrathin sections of strain $\mathrm{Rt} 8 . \mathrm{B} 1^{\mathrm{T}}$ revealed an atypical, gram-positive cell wall with an inner cell wall layer and outer cell wall layer (a monolayer cell wall coated by an inner layer and outer layer having a globular structure). A similar cell wall ultrastructure has been found in Thermoanaerobacter ethanolicus (35) and Thermoanaerobacter thermohydrosulfuricus (31), and this structure is different from the monolayer cell wall structure of Thermoanaerobacter brockii (40) and Thermoanaerobacter finnii (30). Because the cell wall structure of strain $\mathrm{Rt} 8 . \mathrm{B1}^{\mathrm{T}}$ is similar to the cell wall structure of the spore-forming organism Thermoanaerobacter thermohydrosul- furicus and different from the cell wall structure of the other spore formers (Thermoanaerobacter finnii and Thermoanaerobacter brockii), it appears that strain Rt8.B1 ${ }^{\mathrm{T}}$ most closely resembles Thermoanaerobacter thermohydrosulfuricus morphologically.

Thermoanaerobacter wiegelii $\mathrm{Rt} 8 . \mathrm{B} 1^{\mathrm{T}}$ was susceptible to the antibiotics cephalosporin $\mathrm{C}$, erythromycin, bacitracin, tetracycline, and polymyxin B but not to penicillin, ampicillin, or chloramphenicol. Tetracycline has been shown to inhibit the growth of Thermoanaerobacter brockii (40) and Thermoanaerobacter finnii (30) but not the growth of Thermoanaerobacter ethanolicus (35). Penicillin G inhibited the growth of Thermoanaerobacter thermohydrosulfuricus (25), Thermoanaerobacter brockii (40), and Thermoanaerobacter finnii (30), but had no effect on Thermoanaerobacter wiegelii Rt8.B1 ${ }^{\mathrm{T}}$.

Thermoanaerobacter wiegelii Rt8.B1 ${ }^{\mathrm{T}}$ ferments some sugar alcohols and glucosamine, but does not ferment ribose or arabinose. Both ribose and arabinose are fermented by Thermoanaerobacter thermohydrosulfuricus (36); however, glycerol, sorbitol, and glucosamine are not fermented. Strain Rt8.B1 ${ }^{\mathrm{T}}$ did not have the absolute growth requirement for yeast extract or Trypticase described previously for the genus Thermoanaerobacter (37). Both of these growth supplements could be replaced by high concentrations of a vitamin solution (5) and Casamino Acids. These observations and the results described above support our conclusion that strain Rt $8 . \mathrm{B} 1^{\mathrm{T}}$ belongs to a new Thermoanaerobacter species.

Description of Thermoanaerobacter wiegelii sp. nov. Thermoanaerobacter wiegelii (wie.gel'i.i. M.L. gen. n. wiegelii, of Wiegel, in recognition of Juergen Wiegel's contributions to our knowledge of thermophilic anaerobes).

Morphology. Colonies are 0.5 to $2.0 \mathrm{~mm}$ in diameter, smooth, nonpigmented, and uniformly round. Gram-negative rods are 0.4 to $0.6 \mu \mathrm{m}$ wide by 4 to $10 \mu \mathrm{m}$ long. Cells occur singly, in pairs, or (less frequently) in chains. Cells grown in rich TYEG medium do not sporulate. When the organism is grown in a minimal medium (5), the cells are long and filamentous and spores are formed. The spores are round and terminal, distend the cells, and are brightly refractile as determined by phase-contrast microscopy.

Cellular characteristics. The $\mathrm{G}+\mathrm{C}$ content of the DNA is $35.6 \pm 1.2 \mathrm{~mol} \%$ (as determined by the HPLC method). An inner cell wall layer and an outer cell wall layer are present (a monolayer cell wall coated by an inner layer and an outer layer having a globular structure).

Growth characteristics. Obligately anaerobic. The optimum temperature is 65 to $68^{\circ} \mathrm{C}$; the maximum temperature at which growth occurs is 76 to $78^{\circ} \mathrm{C}$. Growth at $38^{\circ} \mathrm{C}$ is poor; no growth occurs at $28^{\circ} \mathrm{C}$. Growth occurs at pH 5.5 to 7.2 ; optimum growth occurs at $\mathrm{pH} 6.8$. The doubling time in glucose-containing medium is $72 \mathrm{~min}$.

Metabolic characteristics. Chemoorganotroph. Utilizes various mono-, di-, and polysaccharides, including glucose, xylose, maltose, lactose, cellobiose, raffinose, glucosamine, galactose, fructose, mannose, sucrose, glycerol, soluble starch, pectin, and chitin. Sorbitol, mannitol, and trehalose are also fermented, but ethanol, DL-lactate, sodium citrate, sodium succinate, transaconitate, malonate, glutamate, glutamine, sodium pyruvate, 2-deoxyglucose, $\alpha$-methyl-glucoside, L-arabinose, dulcitol, $m$-inositol, ribose, $\alpha$-L-fucose, $\alpha$-L-rhamnose, and L-sorbose are not fermented. The products of metabolism during growth on glucose are ethanol, lactate, acetate, $\mathrm{CO}_{2}$, and $\mathrm{H}_{2}$. Propionate is formed during growth on xylose or cellobiose in $\mathrm{pH}$-controlled ( $\mathrm{pH} \mathrm{7)}$ batch cultures. Growth on glucose is inhibited by oxygen, cephalosporin $\mathrm{C}$, erythromycin, bacitracin, tetracycline, polymyxin $\mathrm{B}$, and various metabolic inhibitors. 
Habitat. The habitat is neutral to alkaline freshwater (56 to $69^{\circ} \mathrm{C}$ ) in a geothermally heated water source in Government Gardens, Rotorua, New Zealand.

Type strain. Thermoanaerobacter wiegelii $\mathrm{Rt} 8 . \mathrm{B} 1^{\mathrm{T}}$ was isolated from a freshwater runoff pool from a geothermally heated water source in Rotorua, New Zealand, and has been deposited in the Deutsche Sammlung von Mikroorganismen as strain DSM 10319. Strain Rt8.B1 ${ }^{\mathrm{T}}$ is the only strain that has been isolated so far.

We propose that on the basis of its morphological characteristics, DNA $\mathrm{G}+\mathrm{C}$ content, relatively narrow $\mathrm{pH}$ range for growth ( $\mathrm{pH} 5.5$ to 7.2 ), antibiotic susceptibility, ability to ferment some sugar alcohols, growth in the absence of yeast extract, formation of propionate when it is grown on xylose or cellobiose, and levels of 16S rRNA sequence homology, strain $\mathrm{Rt} 8 . \mathrm{B} 1^{\mathrm{T}}$ should be included in the genus Thermoanaerobacter as a new species, Thermoanaerobacter wiegelii.

\section{ACKNOWLEDGMENTS}

We thank the Meat Industry Research Institute of New Zealand for access to electron microscopy facilities, D. Wild and A. Harris for specimen preparation, and Jutta Burghardt for the $\mathrm{G}+\mathrm{C}$ content determination.

\section{REFERENCES}

1. Ben-Bassat, A., R. Lamed, and J. G. Zeikus. 1981. Ethanol production by thermophilic bacteria: metabolic control of end product formation in Thermoanaerobium brockii. J. Bacteriol. 146:192-199.

2. Carreira, L. H., L. G. Ljungdahl, F. Bryant, M. Szulczynski, and J. Wiegel. 1982. Control of product formation with Thermoanaerobacter ethanolicus, enzymology and physiology, p. 351-355. In Y. Ikeda (ed.), Genetics of industrial microorganisms. American Society for Microbiology, Washington, D.C

3. Carreira, L. H., J. Wiegel, and L. G. Ljungdahl. 1983. Production of ethanol from biopolymers by anaerobic, thermophilic, and extreme thermophilic bacteria. I. Regulation of carbohydrate utilization in mutants of Thermoanaerobacter ethanolicus. Biotechnol. Bioeng. Symp. 13:183-191.

4. Collins, M. D., P. A. Lawson, A. Willems, J. J. Cordoba, J. FernandezGarayzabal, P. Garcia, J. Cai, H. Hippe, and J. A. E. Farrow. 1994. The phylogeny of the genus Clostridium: proposal of five new genera and eleven new species combinations. Int. J. Syst. Bacteriol. 44:812-826.

5. Cook, G. M., P. H. Janssen, and H. W. Morgan. 1991. Endospore formation by Thermoanaerobium brockii HTD4. Syst. Appl. Microbiol. 14:240-244.

6. Cook, G. M., P. H. Janssen, and H. W. Morgan. 1993. Simultaneous uptake and utilisation of glucose and xylose by Clostridium thermohydrosulfuricum. FEMS Microbiol. Lett. 109:55-62.

7. Cook, G. M., P. H. Janssen, and H. W. Morgan. 1993. Uncoupler-resistant glucose uptake by the thermophilic glycolytic anaerobe Thermoanaerobacter thermosulfuricus (Clostridium thermohydrosulfuricum). Appl. Environ. Microbiol. 59:2984-2990.

8. Cook, G. M., P. H. Janssen, J. B. Russell, and H. W. Morgan. 1994. Dual mechanisms of xylose uptake in the thermophilic bacterium Thermoanaerobacter thermohydrosulfuricus. FEMS Microbiol. Lett. 116:257-262.

9. Cook, G. M., and H. W. Morgan. 1994. Hyperbolic growth of Thermoanaerobacter thermohydrosulfuricus (Clostridium thermohydrosulfuricum) increases ethanol production in $\mathrm{pH}$-controlled batch culture. Appl. Microbiol. Biotechnol. 41:84-89.

10. De Soete, G. 1983. A least squares algorithm for fitting additive trees to proximity data. Psychometrika 48:621-626.

11. Germain, P., F. Toukourou, and L. Donaduzzu. 1986. Ethanol production by anaerobic thermophilic bacteria: regulation of lactate dehydrogenase activity in Clostridium thermohydrosulfuricum. Appl. Microbiol. Biotechnol. 24:300-305.

12. Hollaus, F and U. Sleytr. 1972. On the taxonomy and fine structure of some hyperthermophilic saccharolytic clostridia. Arch. Mikrobiol. 86:129-146.

13. Jain, M. K., and J. G. Zeikus. 1992. The genera Thermoanaerobacter, Thermoanaerobium, and other thermoanaerobic saccharolytic bacteria of uncertain taxonomic affiliation, p. 1901-1913. In A. Balows, H. G. Truper, M. Dworkin, W. Harder, and K. H. Schleifer (ed.), The prokaryotes, 2nd ed. Springer-Verlag, New York.

14. Jin, F., K. Yamasato, and K. Toda. 1988. Clostridium thermocopriae sp. nov., a cellulolytic thermophile from animal feces, compost, soil, and a hot spring in Japan. Int. J. Syst. Bacteriol. 38:279-281.

15. Jukes, T. H., and C. R. Cantor. 1969. Evolution of protein molecules, p. 21-132. In H. N. Munro (ed.), Mammalian protein metabolism. Academic Press, Inc., New York.
16. Lamed, R., and J. G. Zeikus. 1980. Glucose fermentation pathway of Thermoanaerobium brockii. J. Bacteriol. 141:1251-1257.

17. Lamed, R., and J. G. Zeikus. 1980. Ethanol production by thermophilic bacteria: relationship between fermentation product yields of and catabolic enzyme activities in Clostridium thermocellum and Thermoanaerobium brockii. J. Bacteriol. 144:569-578.

18. Lee, Y.-E., M. K. Jain, C. Lee, S. E. Lowe, and J. G. Zeikus. 1993. Taxonomic distinction of saccharolytic thermophilic anaerobes: description of Thermoanaerobacterium xylanolyticum gen. nov., sp. nov., and Thermoanaerobacterum saccharolyticum gen. nov., sp. nov.; reclassification of Thermoanaerobium brockii, Clostridium thermosulfurogenes, and Clostridium thermohydrosulfuricum E100-69 as Thermoanaerobacter brockii comb. nov., Thermoanaerobacterium thermosulfurigenes comb. nov., and Thermoanaerobacter thermohydrosulfuricus comb. nov., respectively; and transfer of Clostridium thermohydrosulfuricum 39E to Thermoanaerobacter ethanolicus. Int. J. Syst. Bacteriol. 43:41-51.

19. Leigh, J. A., F. Mayer, and R. S. Wolfe. 1981. Acetogenium kivui gen. nov., sp. nov., a new thermophilic hydrogen oxidizing, acetogenic bacterium. Arch. Microbiol. 129:275-280.

20. Leigh, J. A., and R. S. Wolfe. 1983. Acetogenium kivui, a thermophilic acetogenic bacterium. Int. J. Syst. Bacteriol. 33:886

21. Mesbah, M., U. Premachandran, and W. B. Whitman. 1989. Precise measurement of the $\mathrm{G}+\mathrm{C}$ content of deoxyribonucleic acid by high-performance liquid chromatography. Int. J. Syst. Bacteriol. 39:159-167.

22. Patel, B. K. C., H. W. Morgan, and R. M. Daniel. 1985. A simple and efficient method for preparing and dispensing anaerobic media. Biotechnol. Lett. 7:277-278.

23. Patel, B. K. C., H. W. Morgan, and R. M. Daniel. 1985. Fervidobacterium nodosum gen. nov. and sp. nov., a new chemoorganotrophic, caldoactive, anaerobic bacterium. Arch. Microbiol. 141:63-69.

24. Patel, B. K. C., H. W. Morgan, and R. M. Daniel. 1986. Studies on some thermophilic glycolytic anaerobic bacteria from New Zealand hot springs. Syst. Appl. Microbiol. 8:128-136.

25. Peteranderl, R., E. B. Shotts, Jr., and J. Wiegel. 1990. Stability of antibiotics under growth conditions for thermophilic anaerobes. Appl. Environ. Microbiol. 56:1981-1983.

26. Pirt, S. J. 1975. Principles of microbe and cell cultivation. Blackwell, Oxford.

27. Rainey, F. A., M. Dorsch, H. W. Morgan, and E. Stackebrandt. 1992. 16S rDNA analysis of Spirochaeta thermophila: its phylogenetic position and implications for the systematics of the order Spirochaetales. Syst. Appl. Microbiol. 15:197-202.

28. Rainey, F. A., and E. Stackebrandt. 1993. Transfer of the type species of the genus Thermobacteroides to the genus Thermoanaerobacter as Thermoanaerobacter acetoethylicus (Ben-Bassat and Zeikus 1981) comb. nov., description of Coprothermobacter gen. nov., and reclassification of Thermobacteroides proteolyticus as Coprothermobacter proteolyticus (Ollivier et al. 1985) comb. nov. Int. J. Syst. Bacteriol. 43:857-859.

29. Rainey, F. A., N. L. Ward, H. W. Morgan, R. Toalster, and E. Stackebrandt. 1993. Phylogenetic analysis of anaerobic thermophilic bacteria: aid for their reclassification. J. Bacteriol. 175:4772-4779.

30. Schmid, U., H. Giesel, S. M. Schoberth, and H. Sahm. 1986. Thermoanaerobacter finnii spec. nov., a new ethanologenic sporogenous bacterium. Syst. Appl. Microbiol. 8:80-85.

31. Sleytr, U. B., and A. M. Glauert. 1976. Ultrastructure of the cell walls of two closely related clostridia that possess different regular arrays of surface subunits. J. Bacteriol. 126:869-882.

32. Smibert, R. M., and N. R. Krieg. 1981. General characterization, p. 409-425. In P. Gerhardt, R. G. E. Murray, R. N. Costilow, E. W. Nester, W. A. Wood, N. R. Kreig, and G. B. Phillips (ed.), Manual of methods for general bacteriology. American Society for Microbiology, Washington, D.C.

33. Wiegel, J. 1980. Formation of ethanol by bacteria. A pledge for the use of extreme thermophilic anaerobic bacteria in industrial ethanol fermentation processes. Experientia 36:1434-1446.

34. Wiegel, J. 1992. The obligately anaerobic thermophilic bacteria, p. 105-184. In J. K. Kristjansson (ed.), Thermophilic bacteria. CRC Press, London.

35. Wiegel, J., and L. G. Ljungdahl. 1981. Thermoanaerobacter ethanolicus gen. nov., sp. nov., a new extreme thermophilic, anaerobic bacterium. Arch. Microbiol. 128:343-348.

36. Wiegel, J., L. G. Ljungdahl, and J. R. Rawson. 1981. Isolation from soil and properties of the extreme thermophile Clostridium thermohydrosulfuricum. J. Bacteriol. 139:800-810.

37. Wiegel, J. K. W. 1986. Genus Thermoanaerobacter, p. 1379-1383. In P. H. A. Sneath, N. S. Mair, M. E. Sharpe, and J. G. Holt (ed.), Bergey's manual of systematic bacteriology, vol. 2. The Williams and Wilkins Co., Baltimore.

38. Winter, J., and G. Zellner. 1990. Thermophilic anaerobic degradation of carbohydrates-metabolic properties of microorganisms from the different phases. FEMS Microbiol. Rev. 75:139-154.

39. Zeikus, J. G., A. Ben-Bassat, and P. W. Hegge. 1980. Microbiology of methanogenesis in thermal, volcanic environments. J. Bacteriol. 143:432-440.

40. Zeikus, J. G., P. W. Hegge, and M. A. Anderson. 1979. Thermoanaerobium brockii gen. nov. and sp. nov., a new chemoorganotrophic, caldoactive, anaerobic bacterium. Arch. Microbiol. 122:41-48. 